\title{
Study on Students' Career Planning of Southwest Petroleum University
}

\author{
Zhihua Zhang, Hechao Tian \\ School of Mechanical Engineering, Southwest Petroleum University, Chengdu, China \\ Email: zzh20151118@163.com
}

Received 27 November 2015; accepted 26 January 2016; published 29 January 2016

Copyright (C) 2016 by authors and Scientific Research Publishing Inc.

This work is licensed under the Creative Commons Attribution International License (CC BY). http://creativecommons.org/licenses/by/4.0/

(c) (i) Open Access

\begin{abstract}
In recent years, the college students in southwest petroleum university face tough test to find a job, with the deeper reform of higher education and increasingly change form of employment. It seems important for high college managers to carry out the career guidance for college students. In social reality, there are many companies wouldn't find a satisfying job hunter by different ways, compared with the increasing people of unemployed college student, there is a saying that talents but not required. There is a gap between the cultivation of talents and the demand of the society. With the increase enrollment of college students, in this era of intense competition, how to pale others by showing their talent, how to put their skills, abilities and enterprise needs to achieve seamless docking, which is a problem that worth deep thinking. Based on a task related questionnaire survey in southwest petroleum university, this article analyzes data, summarizes southwest petroleum university's current students career planning problems, dialyses the causes of these problems, and puts forward the correspondingly feasible suggestions to improve southwest petroleum university students' career planning.
\end{abstract}

\section{Keywords}

College Students, Career, Career Planning, Southwest Petroleum University

\section{Introduction}

Nowadays, college students in southwest petroleum university have to face and solve a problem, which is between college students and corporations. In college, students are almost in the face of the theory learning. Knowledge and skill are still stay in a relatively shallow level of understanding (Costa Neto, 2004). There is a gap between the level of the enterprise's demand for talent and the pure theory. College students had gotten rid of the pressure of the college entrance examination and entered the university gate. Thus, they seemingly abandoned a long career out of university study and feeling themselves learned nothing when they graduate. Career 
planning (Costa Neto \& Carvalho, 2000) for college students is a beacon for most college students who are facing helpless, unplanned and aimless psychological (Freire, 2002). Career spans most precious life energy primetime, so everybody wants to get hone and growth from career. Not entering the job market for college students, they can make their own learning and lifelong career have a direction by planning career (Grigoroudis \& Siskos, 2002). Around this direction, college students can make full use of university life, constantly play to their potential and achieve their goals in life by effort.

\section{Status and Problems of Student Career Planning}

\subsection{The Analysis of Student Career Planning's Status}

In order to analyze the status of student career planning, we put out 2000 questionnaires, and 1980 questionnaires are available. In this investigation, about $77 \%$ are boy students, and $23 \%$ are girl. $37 \%$ of the respondents in this investigation come from towns and mid-sized cities, and $43 \%$ of the respondents come from rural area, and $50 \%$ of the rural area students come from Sichuan province. This questionnaire mainly concerns about the student career planning's teaching content, teaching method, student's recognizing about career planning and the implement of career planning of ideological and political education.

In the process of questionnaire survey, there are $58 \%$ students think it isn't conformity when they had been asked about the faculty of their major whether have courses to tutor Student Career Planning. For them, only 15\% students choose option "absolute conformity" and about 32\% students think it's just conformity. In the survey of students whether understand some knowledge of how to plan career, $46 \%$ students choose that they don't understand. The others students said that they know how to plan career. In the results of survey, the organization of career planning is the school's center of employment direction and the deploy of persons qualified to teach is appreciable. However, it is only related to a number of major economic management. Most of courses have no tutors who can teach students about career planning. Survey shows that about $57 \%$ students get the knowledge of their career by Internet. There is no professional teachers who are major in career direction in their school's employment direction center (Grigoroudis \& Siskos, 2009).

\subsection{Problems of Career Planning}

\subsubsection{The Lack of Knowledge of Career Planning}

Across the survey, there are just $62 \%$ students realize the knowledge of career planning. There are $59 \%$ of students said that the faculty of their major have no courses about career planning. In addition, 64\% students think the career planning is so meaningful to their own. Thus, $29 \%$ of students don't know the career planning knowledge. University stages of learning has changed from rote to completely free of subjective time, but students lack of rational thinking and planning for career. A lot of students think that career planning is meaningless to themselves. There is a conflict between feeling of existence and true meaning on the problem of career planning. The realization level of career planning's knowledge has a great effect students' attitude of studying hard and precise location of their own career (Harvey \& Green, 1993).

\subsubsection{Learning Lack of Planning and Not Involving the Scientific Self Assessment}

In the survey about satisfaction of students' major, there are $44 \%$ of students think they that they are dissatisfied with their own major. From the survey data, almost the half of students are dissatisfied with the major what they are learning. Besides, 52\% students have no plan about their own study. In the area of Taiwan and Hong Kong, Selection guidance and employment guidance are generally (Ham \& Hayduk, 2003). A lot of universities pass a variety of methods of evaluation. It can be a reference when students choose major and find jobs. But on the mainland, college students did not carry out the relevant evaluation work. Students' sight is blinkered about major selection, some students even choose major blindly. The mistakes of major selection make a part of students lack initiatives and interest. The reason why most students have no consciousness of career planning and study lacks planned is that students personal professional awareness is not strong and the school did not have a timely manner to the students to carry out professional ideas (Harvey \& Knight, 1996).

\subsubsection{Lack of Social Practice, Career Goals Fuzzy}

There are 61\% students didn't attend the social practice, which is relate to their own major. During a year, students without accurate plan about recognize themselves, how to study, goal of career and changing communica- 
tion range (Harvey \& Williams, 2010). Career planning establishes based on self evaluation, environmental analysis and target determination. At the same time, it is a process that should be implement strategy and measures according to career goals and be feedback and adjust continually. Among them, environmental analysis plays an important part in the career planning. Without support of environmental analysis, career planning is just an air building. The successful development of career planning should be established on sufficient self evaluation and environmental analysis. For college students, the most useful way to realize the external environment is social practice. The weak social practice has a bad influence with the realization of the whole external professional environment. Because students are lack of realization of the professional environment, they have no a accurate career goal. At the same time, according to the environmental cycle, students can't timely correct self disadvantage and all aspects of planning.

\subsection{The Problems and Reasons of Career Planning}

\subsubsection{The Lack of Social Practice and the Shallow Consciousness of Career Planning}

$60 \%$ of college students have never experienced a social practice that closed with their major, which caused some students couldn't clearly understand what quality of talents is required, they also don't know how severe the employment situation is. Many college students don't have the sense of urgency about career planning, they also don't realize the importance of career planning, so they are lack of awareness of career planning (Hendry \& Dean, 2002). When finding jobs, there are students ignored the development space and development prospects of their job, they just care about salary and fringe benefits, they don't think about self condition and social needs, hazy vocational values make them couldn't have a exact realize about what job they like and suit them, it's obvious that the lack of career planning caused much pressure for employment. College students are the main subject of career planning, the education of the school is only a guide, the real known depends on the students self consciousness (Hutyra, 2005).

\subsubsection{Unreasonable Career Planning Curriculum Setting}

Mastering the knowledge of career planning is the rational prerequisite of the college students in southwest petroleum university' career planning. through a investigation, only $10 \%$ of the students have a career planning course, this shows that the knowledge of career planning is not wide (Koilias, Kostoglou, Garmpis, \& Van der Heijden, 2011). Only a few college setting this course. The school's curriculum setting is not reasonable, what makes only a few of students have learned the theory of career planning, others could know this just by papers, magazines or network, they will inevitably know not comprehensive, meanwhile, incorrect understanding of career planning may cause adverse effects for their learn plan (Martensen, Grnholdt, Eskildsen, \& Kristensen, 2000). In the interview, when asked about their future career planning, some students don't know what to say. If we don't have a clear career planning, the interviewer would think that we won't work here for a long time, this may have a negative impact for job hunting.

\subsubsection{The Organization of the School Is Not Complete, the Teacher Is Not Enough}

The correct career planning could help define the goals, reduce the blindness of choosing a career. 66\% of college students study the occupation without teachers' guide, more students get information through internet, The students' understanding of occupation and the future employment situation is based on professional career planning guidance, learning career planning by ourselves will unavoidable get a misunderstanding about occupation, and we can’t develop career plans according to our own circumstances (Shemwell, Yavas, \& Bilgin, 1998). The employment Guidance Center is the only one institution that focus on career planning, and the teachers who work in it just give out a little employment information, and most of colleges arrange Instructors to supplely explain different occupations, most of Ideological and political teachers are not professional, their guidance are only theory, because of the lack of profession career planning teachers, many students' known about career is not comprehensive, makes their study goals unclear and couldn't identify their employment orientation (Lagrosen, Seyyed-Hashemi, \& Leitner, 2004).

\subsubsection{Employment Publicity and Professional Evaluation of Resource Service Is Not in Place}

At present, employment guidance center just a mechanism that give out Job information and employment information statistics, their work about career planning guidance and education is not enough, and they don't 
spend too much time on employment guidance, Especially on propagandizing the importance of career planning guidance, this makes college students don't correctly treat Career planning (Schertzer \& Schertzer, 2004). The necessary condition of the occupational planning is to realize the conditions of the self and the external environment. Professional evaluation software is an effective tool to understand our own. There are few students have ever experienced professional test, without professional test software, a few students get a self assessment based on psychological test and network test, the lack of professional evaluation software caused college students don’t have a comprehensive understanding on Self cognition and job matching.

\section{The Methods to Improve the Career Planning}

Nowadays, the career planning have been still faced with numerous problems in Southwest Petroleum University, which have shaped into in many aspects, including individual, school, society and so on (Shrikanthan \& Dalrymple, 2003). Improving the guidelines of career planning and promoting the occupation of university students are mainly matters for us, and it needs us positively to take a series of measures to make better university students' occupations of planning. But to university students, the occupation of planning is a complex and systematic project, it is hard to accomplish with individual. Therefore, it need to make many common efforts with society, school and personal (Shure, Jansen, \& Harskamp, 2007).

\subsection{Facilities Construction of Software and Hardware in Occupation Planning}

\subsubsection{The Team Construction of the Organization and Faculty of the Career Planning}

Southwest Petroleum University should realize what the importance of career planning about capacity promoted students and schools' development chronically, departments relative should regard the career planning's organization and teaching staffs' construction to an essential work schedule. Meanwhile, employment Guidance Center's relative departments build instructional groups which have been owned profession and quality, forming a number of professional knowledge, application of the ability to guide the professional career planning education team which have encouraged students to participate in, and carry out randomly professional career guidance abilities' training to them (Sureshchandar, Rajendran, \& Anantharaman, 2002). In the basis of construct high-quality and high-level professional teachers, the model of education is mainly professional teachers, Combined with the professional career research experts, the practical experience of the enterprise human resources management professional personnel, supplemented by the multilevel teaching methods, and constantly improve the professional teachers of students career planning guidance. Career planning guidance should be carried out in the whole school, to mobilize the enthusiasm of students career planning knowledge, teachers can organize students to establish Career Planning Association, Resume Association, professional career debate and other forms, to form their own professional team, and to improve students' career planning initiative. Professional teachers not only develop theoretical directions, but also establish the practice of occupation planning (Van Kemenade, Pupius, \& Hardjono, 2008). For example, in the form of a professional career simulation contest, it can be operated, stimulate learning interest, guide students to realize their own advantages and disadvantages, and make full use of students' personality, interests, hobbies, talents and their professional skills, comprehensive and reasonable professional career and professional students, in order to achieve the full implementation of the career planning.

\subsubsection{Rationally Set up Career Planning Course}

Career planning courses should not be limited to a number of professional school and its relevant professional, in the whole school, according to the situation of each college set up a compulsory course and elective course, starting from the first grade to carry out career planning guidance, and to run through the whole study, the curriculum into normal teaching plan. In the teaching method, avoiding the simple theory to explain, the practical case and the interest teaching in the professional career planning to introduce them, for different grade students, the situation is different, the general career planning guidance should be based on the different levels of the different levels of teaching.

During the first stage, for students career planning guidance, the sooner, the better, the first stage is that students interesting in new things just have a short period, especially students in freshman period, whether it is the ideological and political teachers in schools or special employment guidance institutions, through the regular organization of propaganda and education, to students of self cognition and career awareness education and 
guide, encourage students to actively participate in the activities organized by the school, be good at from participating in activities found their own strengths, advantages and disadvantages. Helping students to learn as soon as possible, the students are not interested in the professional direction adjustment, so as to make the role of the students as soon as possible, through the professional training of students' vocational interest, on the basis of vocational training to develop learning plan, guide students to establish a correct concept of occupation.

During the second stage, after a year of study, students understand their professional characteristics, the school should be regularly carried out by professional experts, successful lectures, entrepreneurs into the campus and other ways, so that students to enhance their professional training objectives and prospects for employment, so that students understand the importance of professional learning, training students to deepen their knowledge of learning enthusiasm, at the same time on the basis of professional knowledge, to achieve a wide range of knowledge, professional knowledge, for the comprehensive quality of the foundation. To guide students through various means to understand the requirements of individual quality of the professional team, so that students have the basic knowledge of the improvement of the skills of the individual's comprehensive quality requirements, and learn through various ways to effectively improve these skills.

During the third stage, in this stage, schools keep on strengthening study of professional knowledge, guide students to combine professional knowledge and practice, encourage students to actively participate in various practical activities, focus on training students social practice ability, understand themselves from the practice, at the same time to guide students what improve their shortcomings, in the strengthening of professional knowledge learning and practice, guide students to improve their comprehensive quality, encourage students to start their own business. Guide students to according to their own interests and professional quality, choose to continue their education or graduate employment issues to give advice, schools should be carried out regularly career sand table simulation and career assessment activities, let students see their true from the scenario simulation and testing results.

Grade four is the sprint link of career planning in the four years of university life. To let students understand the differences between studying and working, know the differences between school and workplace, guide them to adapt themselves to the role transformation from student to career people smoothly, build for their career development by the figures interviews with career people, practice or probation, etc. At the year of grade four, it's important to students know various channels for jobs, let them make good use of the resources in school, the information on the employment information website of school and Large recruitment outside school to get jobs. And let them take an active part in Job fair, establish a good attitude to the competition in the workplace, find a good job when they graduate successfully.

\subsection{Improvement Measures in Career Planning by Students Themselves}

Students should do it themselves that the career planning and implementing, they have to be responsible for their whole career planning. And there are some ways for university students to do: raise and improve the awareness of career planning, do self-appraisal and understanding of external environment through scientific methods, make personal occupation fixed position accurately, set objective and realistic career goals, especially do not reach for what is beyond your grasp, do self-ability cultivation properly to achieve your career goals.

\subsubsection{Improve the Awareness of Career Planning \& Make Scientific Self-Appraisal}

Southwest Petroleum University students should have full understanding of the important influence of career planning on themselves' study, finding jobs and development for one' s career. They need to know the significance that career planning on themselves, put the making and studying of career planning into their daily lives. The basic link of career planning is make a correct self-evaluation, if once there is wrong, that may cause big problems.

\subsubsection{Self-Psychological Test Method}

By filling in standard test table, the test results can be recognized by the tester to understand their own personality, interests, psychological quality, etc. University students can use the scientific self-psychological test for self-analysis and evaluation. In order to get the scientific and accurate test results, fill the table on an objective basis, self-psychological test can be more correct to sum up some of their own. 


\subsubsection{Develop Practical Career Planning Objectives}

To establish career planning goals is the key, Southwest Petroleum University students can use the mind map in the analysis based on the internal and external environment to make a clear draw for their own professional planning objectives. Mind map is the use of the human brain thinking to expand the model of the problem, the status, etc. In the application of the target, it can greatly improve the reality of the target. The graphic example of the mind map is similar to the human brain, which is also similar to the structure of the root. Using mind map for goal setting, there must be the logical order, the middle is their core target, According to the core of the core objectives, draw their own basic information, including basic information, personality traits, interests and abilities, etc. Each of the items included in the map can be the center of thoughts, and from the centers they could spread out thousands of joints, each of the joints represents a link to the central theme of the self. In particular, the formulation of professional objectives should be consistent with the individual's own conditions, in addition, according to the individual's own conditions to develop career goals to adapt to changes in the external environment.

\subsection{Measures for the Difference of Career Planning}

Gender differences: Boys should strengthen the learning plan, according to their own conditions and environmental factors in time to adjust their career goals, and girls should get the professional information through newspapers, magazines, for their own professional goals, they should be envisaged, set their own clear career goals which based on their own learning plan.

Differences of student cadres: In the target planning and feedback correction, the student cadres performance and excellent than non-student cadres. Student cadres should play a leading role in guiding students to participate in various activities of the school and class organizations, so that students find their own highlights and shortcomings in the activities, the feedback on their own.

Only child difference: Only children need to get rid of the point of view that anything depends on their parents, and take part in social practice actively, through social practice, to develop their own learning plan and career goals.

Differences in arts, science and other disciplines: Sports professional and art students need to get know the basic ability of their professional goals through various means, the liberal arts students in the development of professional goals should be improved. In terms of professional exploration and social practice, the relevant guidance teachers should pay attention to guide the students to strengthen the fact that the professional quality, professional exploration and social practice are somehow lack of awareness.

For grade differences: employment guidance departments and professional career planning professional in School should set a reasonable of career planning courses, carry out different career planning knowledge guidance, put out a step-by-step approach to teaching, according to the different grades of different situations.

\section{Conclusion}

Facing society today, in the increasingly fierce competition, career planning is a long-term and systematic project which can't be ignored in the development of one's life. We must pay close attention to it. Having a career planning is a necessary condition for the development of personal career smoothly. From the perspective of enhancing the competitiveness of southwest petroleum university students, the application of career planning in university students is of great significance. The establishment of southwest petroleum university students' career planning system, which can improve the students' career planning guidance-education level, also give inspiration and reference for other colleges and universities.

\section{References}

Costa Neto, E. M. (2004). Insects That “Offend”: Artropodoses Vision of the Residents of the Serra da Jibóia, Bahia, Brazil. Sitientibus Série Ciências Biológicas, 4, 59-68.

Costa Neto, E. M., \& Carvalho, P. D. (2000). Perception of Insects by Graduates of the State University of Feira de Santana, Bahia, Brazil. Acta Scientiarum, Maringá, 22, 423-428.

Freire, P. (2002). Pedagogy of Autonomy. Knowledge Required for Educational Practice (25th ed.). Sao Paulo, SP: Paz e Terra.

Grigoroudis, E., \& Siskos, Y. (2002). Preference Disaggregation for Measuring and Analyzing Customer Satisfaction: The 
MUSA Method. European Journal of Operational Research, 143, 148-170. http://dx.doi.org/10.1016/S0377-2217(01)00332-0

Grigoroudis, E., \& Siskos, Y. (2009). Customer Satisfaction Evaluation. Oklahoma: Springer.

Ham, L., \& Hayduk, S. (2003). Gaining Competitive Advantage in Higher Education: Analyzing the Gap between Expectations and Perceptions of Service Quality. International Journal of Value-Based Management, 16, 223-242. http://dx.doi.org/10.1023/A:1025882025665

Harvey, L., \& Green, D. (1993). Defining Quality. Assessment and Evaluation in Higher Education, 18, 9-34. http://dx.doi.org/10.1080/0260293930180102

Harvey, L., \& Knight, P. T. (1996). Transforming Higher Education. Buchingham, Society for Research into Higher Education, Open University Press.

Harvey, L., \& Williams, J. (2010). Fifteen Years of Quality in Higher Education. Quality in Higher Education, 16, 3-36. http://dx.doi.org/10.1080/13538321003679457

Hendry, G. D., \& Dean, S. J. (2002). Accountability, Evaluation of Teaching and Expertise in Higher Education. International Journal for Academic Development, 7, 75-82. http://dx.doi.org/10.1080/13601440210156493

Hutyra, M. (2005). Quality Management System as the Part of University Management. Paper Presented at Integrating for Excellence, Sheffield, 15-17 June 2005.

Koilias, C., Kostoglou, V., Garmpis, A., \& Van der Heijden, B. (2011). The Incorporation of Graduates from Higher Technological Education into the Labour Market. Journal of Service Science and Management, 4, 86-96.

http://dx.doi.org/10.4236/jssm.2011.41012

Lagrosen, S., Seyyed-Hashemi, R., \& Leitner, M. (2004). Examination of the Dimensions of Quality in Higher Education. Quality Assurance in Education, 12, 61-69. http://dx.doi.org/10.1108/09684880410536431

Martensen, A., Grnholdt, L., Eskildsen, J. K., \& Kristensen, K. (2000). Measuring Student Oriented Quality in Higher Education: Application of the ECSI Methodology. Sinergie-Rapporti di Ricerca, 18, 371-383.

Schertzer, C. B., \& Schertzer, S. M. B. (2004). Student Satisfaction and Retention: A Conceptual Model. Journal of Marketing in Higher Education, 14, 79-91. http://dx.doi.org/10.1300/J050v14n01_05

Shemwell, D. J., Yavas, U., \& Bilgin, Z. (1998). Customer-Service Provider Relationships: An Empirical Test of a Model of Service Quality, Satisfaction and Relationship Oriented Outcome. International Journal of Service Industry Management, 9, 155-168. http://dx.doi.org/10.1108/09564239810210505

Shrikanthan, G., \& Dalrymple, J. F. (2003). Developing a Holistic Model for Quality in Higher Education. Quality in Higher Education, 8, 215-224. http://dx.doi.org/10.1080/1353832022000031656

Shure, C. J. M., Jansen, E. P. W., \& Harskamp, E. G. (2007). Impact of Degree Program Satisfaction on the Persistence of College Students. Higher Education, 54, 207-226. http://dx.doi.org/10.1007/s10734-005-2376-5

Sureshchandar, G. S., Rajendran, C., \& Anantharaman, R. N. (2002). The Relationship between Service Quality and Customer Satisfaction-A Factor Specific Approach. Journal of Services Marketing, 16, 363-379. http://dx.doi.org/10.1108/08876040210433248

Van Kemenade, E., Pupius, M., \& Hardjono, J. W. (2008). More Value to Defining Quality. Quality in Higher Education, 14, 175-185. http://dx.doi.org/10.1080/13538320802278461 